\title{
NUANCES OF PLUMBING IN HIGH RISE BUILDINGS
}

\author{
P. Ramachandran \\ Managing Director, $G R$ Tech Services Private Limited, Irimpanam, Ernakulum, Kerala, India
}

\begin{abstract}
There is a need for close co-ordination between the Plumbing Engineer and other stakeholders of the project such as the Owner, Architect, Structural Engineer and other services. It is only through this effective interaction an efficient plumbing system can be evolved. There is also an urgent need for the plumbing professional to be multidisciplinary in his approach.
\end{abstract}

Keywords: Plumbing Engineer, Structural Engineer

\section{INTRODUCTION}

A frequently asked question pertains to the different approaches required in designing plumbing installations for various types of projects. The answer is that the basic principles of plumbing do not vary.

The laws governing hydraulics dictate the delivery of water at the right temperature, quantity and pressure. Similarly, drainage and venting are governed by time tested engineering basics.

However in the case of multistory buildings especially for residential apartments, tall commercial structures like hotels, hospitals and office complexes the interface between plumbing installations and the structure definitely requires an indepth analysis.

The interaction between the Plumbing Consultant, Architect and the Structural Engineer has to be from the conceptualisation of the projects. These days, the evolution of precast technology, post / pre-tensioned structures necessitates that the potential areas of conflict between the plumbing installations and the structure be resolved. Only then can we hope for a plumbing installation which

- $\quad$ is easy to install.

- does not affect the stability of the structure.

- $\quad$ adds to the aesthetics.

- facilitates maintenance.

Since the audience is primarily composed of Civil Engineers the focus of this paper will be on the inputs required from a Plumbing Engineer to facilitate the Architect and Structural Consultant in delivering a plumbing friendly building. This will form Part A of this Presentation.

Additionally I will also be briefly touching upon the need for the evolution of the Plumbing Engineer in Part B.

\section{Part A - Conflict Resolution Between Plumbing Installation and The Structure}

\section{A.1. Design of Plant rooms adjacent to basements}

In cases where the plant rooms are located in the basements it is ideal to have a common wall between the tank and the plant room. In the event the walls are different the pipes connecting the two structures can fracture due to differential settlement of the two structures.

We also recommend the floor of the plant room to be higher than the basement floor to facilitate flooded suction to pumps and cater for easy cleaning of tanks. Refer sketch - 1, 2 and 3 in this regard.
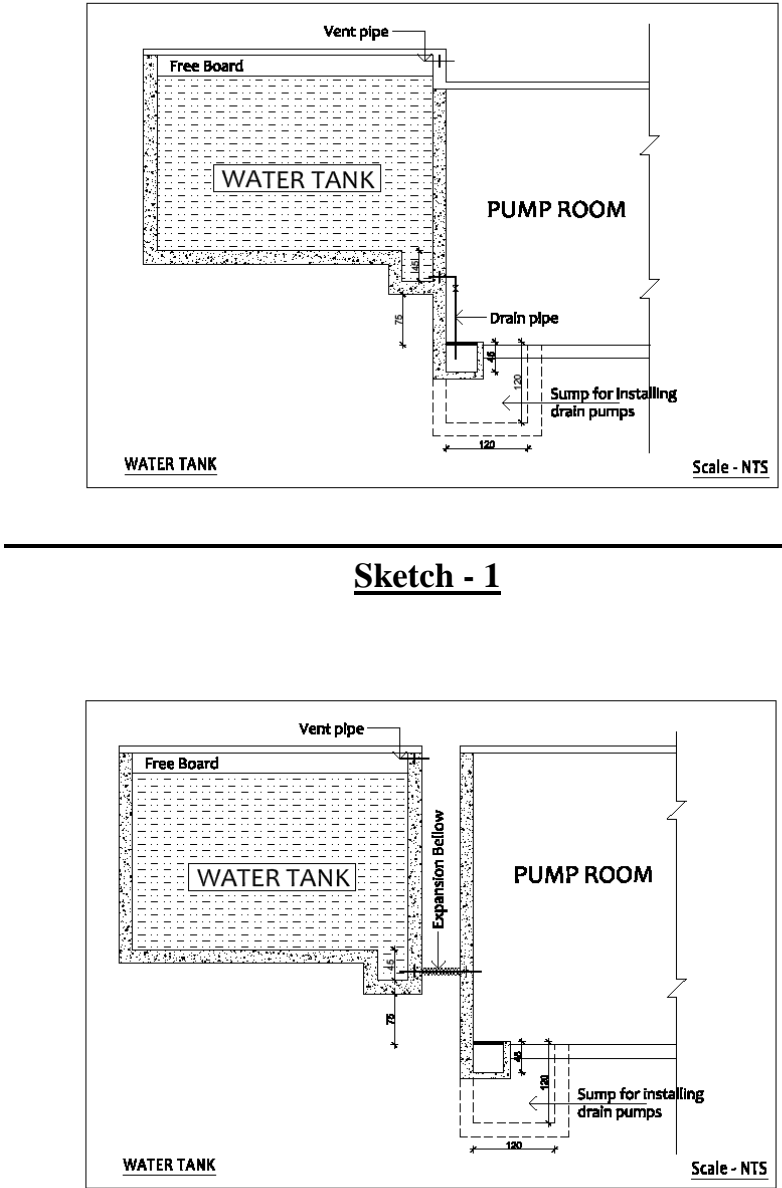

$\underline{\text { Sketch }-2}$ 


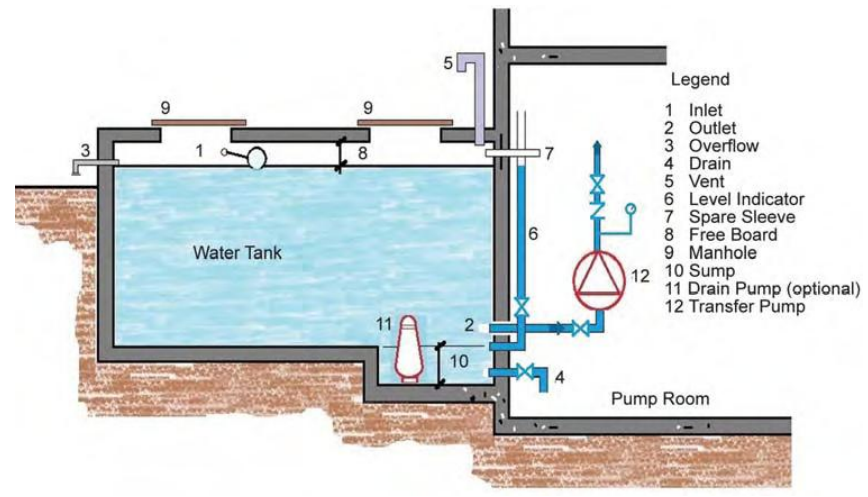

(Note: Drain pump is optional)Water Tank Details

Extracted from A Guide to Good Plumbing Practices (AGGPP)

$\underline{\text { Sketch - 3 }}$

\section{A.2. Design of drains for basements}

Basements require drains at the entrance to trap rainwater from the ramps leading to it. Additional drains are required to drain fire sprinkler bursts accidentally or otherwise. These drains have to be led to adequately sized sumps fitted with pumps to forcibly evacuate the water and keep the basement dry.

\section{A.3. Sizing of Shafts / Access}

Plumbing shafts may need to accommodate the following ( Table- 1). Consequently there is no answer to the question as to what is an adequate duct size. Additionally it is essential to provide access preferably from a public space to service the installation. This may not be possible always. Where possible provide access from balconies. In the event none of this is possible the duct should have cat ladders and cat walls to enable access. Refer sketches 4, 5, 6 \& 7 .

Table - 1: Extracted from A Guide to Good Plumbing Practices (AGGPP)

List of services in plumbing shaft
1. Cold water supply, domestic
2. Hot water supply, flushing
3. Hot water supply
4. Hot water return
5. Isolation and regulating valves for above
6. Domestic water riser to OHT
7. Flushing water riser to OHT
8. Rain water leader (down-take)
9. Soil stack (one or more)
10. Waste stack (one or more)
11. Vent stack (one or more)
12. Shaft drain and drain stack
13. Access door from toilet/passage
14. Toilet exhaust
15. Working platform
Additional services accommodated in plumbing shaft
16. Water heaters
17. Flush tanks or flush valves
18. HVAC pipes
19. Artificial ventilation
20. Artificial lighting

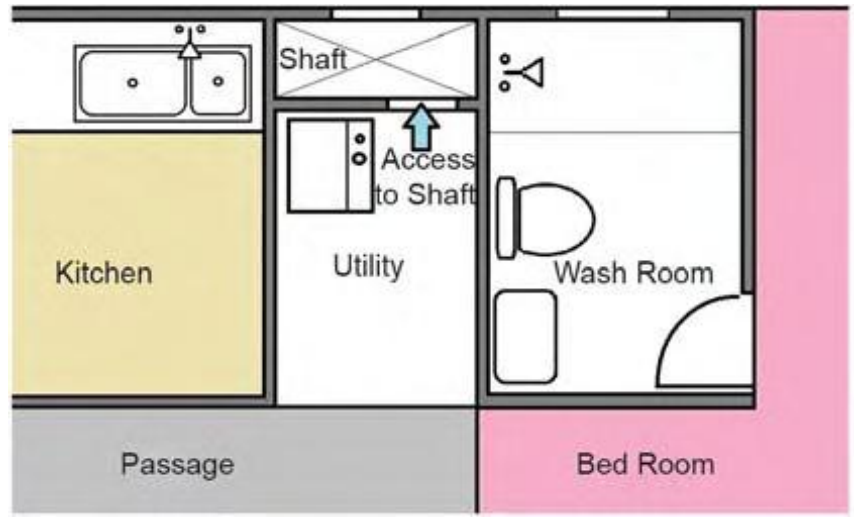

$\underline{\text { Sketch }-4}$

Extracted from A Guide to Good Plumbing Practices (AGGPP)

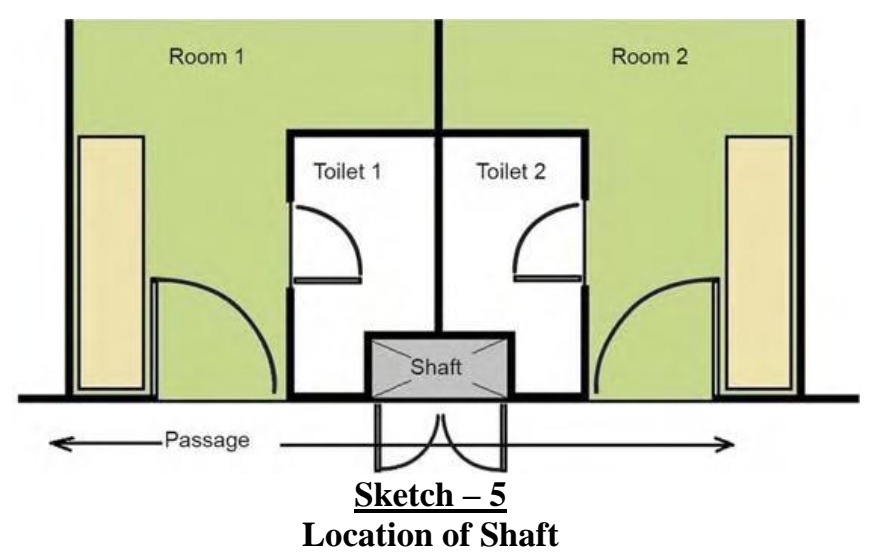

Extracted from A Guide to Good Plumbing Practices (AGGPP)

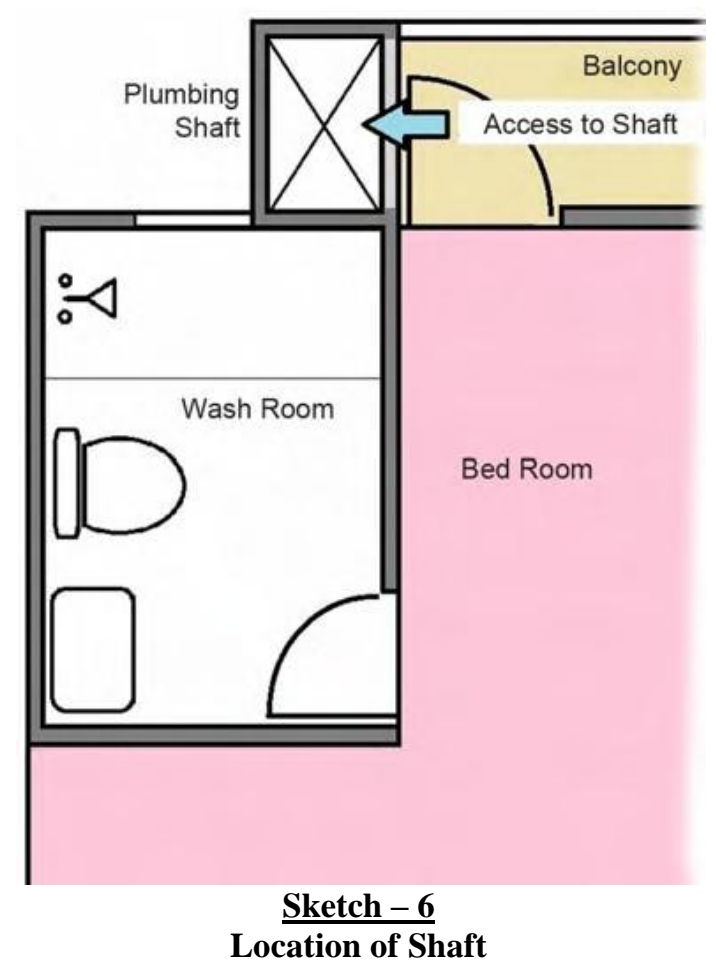

Extracted from A Guide to Good Plumbing Practices (AGGPP) 


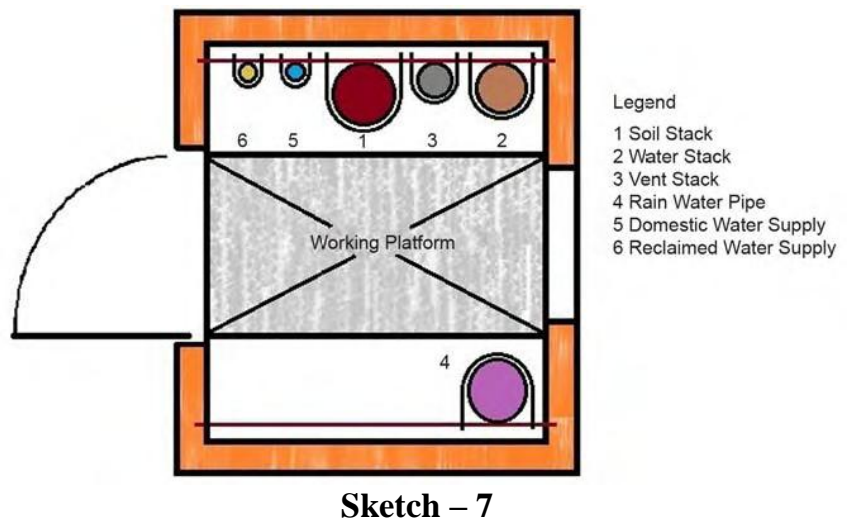

Extracted from A Guide to Good Plumbing Practices (AGGPP)

\section{A.4. Sinking of floors}

The current trend is to minimize sinking of toilets and have drainage pipes suspend below the ceiling. Care has to be taken to ensure that the pipes can be transferred below the peripheral beams enroute to the shaft. Sketches $8,9 \& 10$ attached explain this concept.

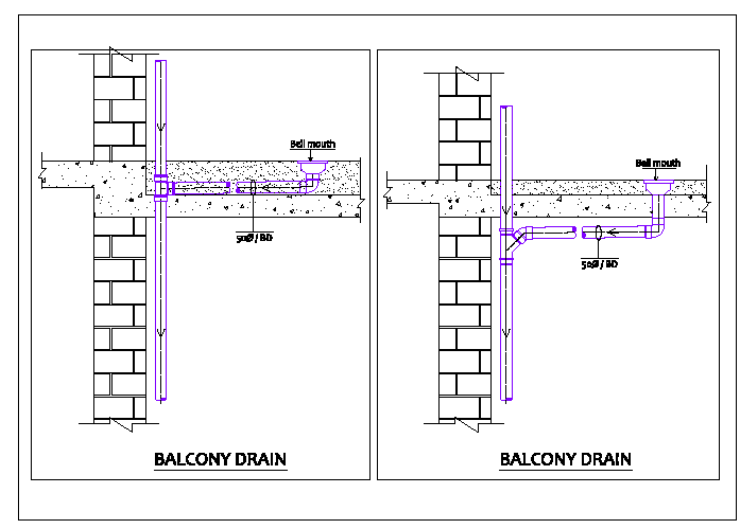

$\underline{\text { Sketch }-8}$

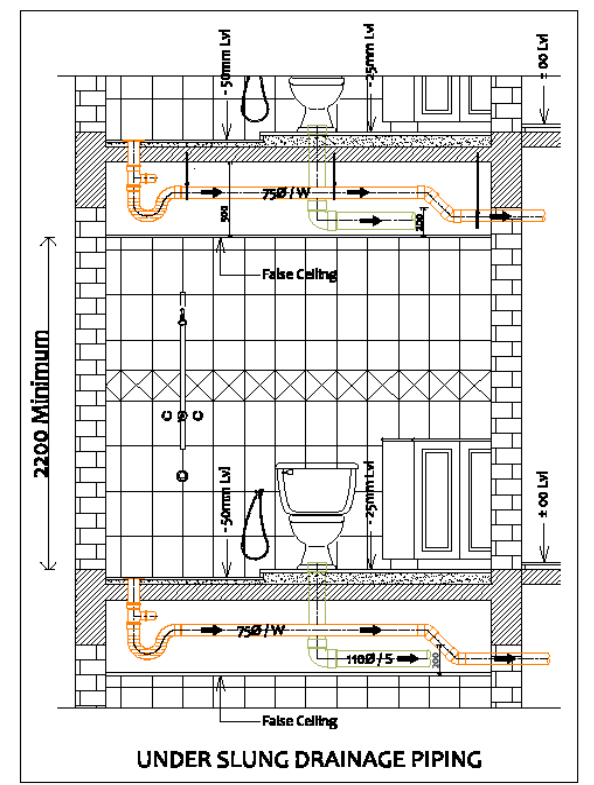

Sketch -9

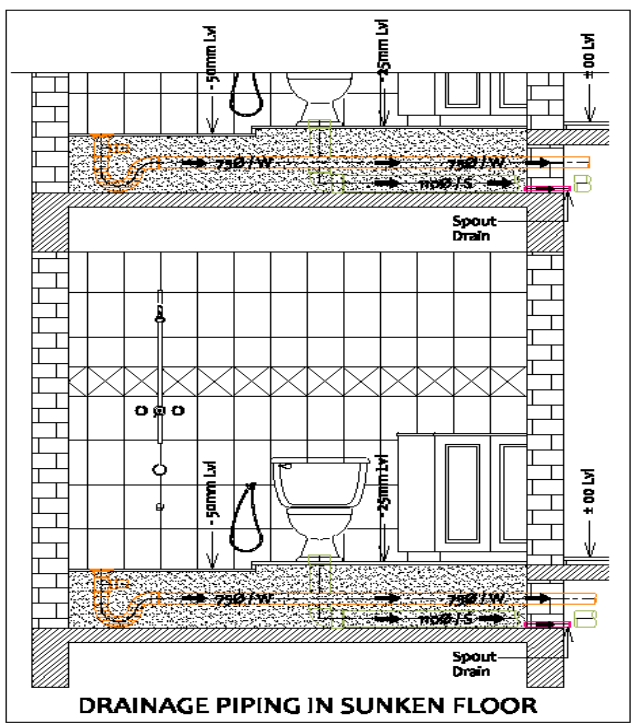

$\underline{\text { Sketch }-10}$

\section{A.5. Core cutting}

There are two problems associated with this. One is the obvious one of a water proof sealant around the sleeve especially in wet areas. This can be easily addressed by using numerous proprietary antishrink grouts and a good applicator. However the problem arises when the coring is through beams / columns / pt slabs and other such structurally vital components. The answer is adequately designed cutouts planned during the design. Care is to be taken to ensure their positions are not altered during concreting. For water supply pipes, puddle flanges inserted during concreting will suffice. Sleeves for drainage pipes are a little more tricky. If unavoidable cutouts are recommended.

\section{A.6. External Drainage}

Manholes and pipes in unstable soil like clay are prone to sinking. A knowledge of subsoil conditions is essential to enable the structural design of these elements. Refer pics $-1 \& 2$ which show effects of settlement.

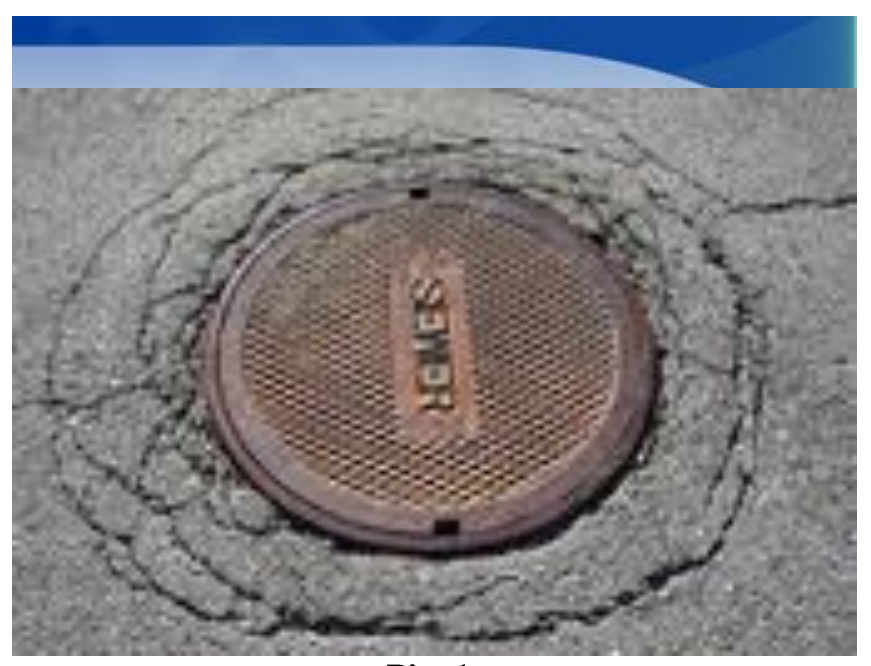

Pic- 1 


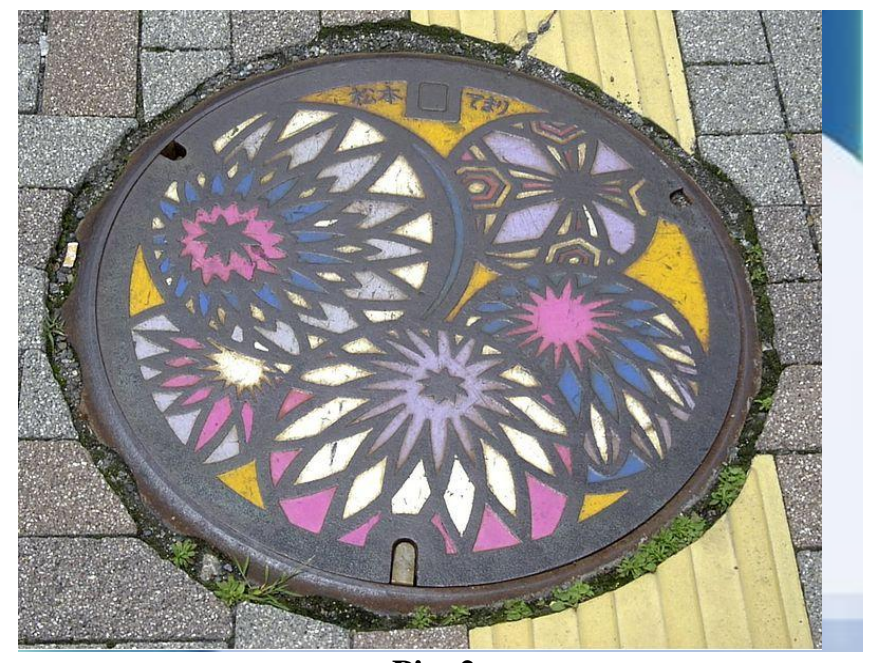

Pic- 2

The sketch below is a schematic of settlement due to poor subsoil conditions.

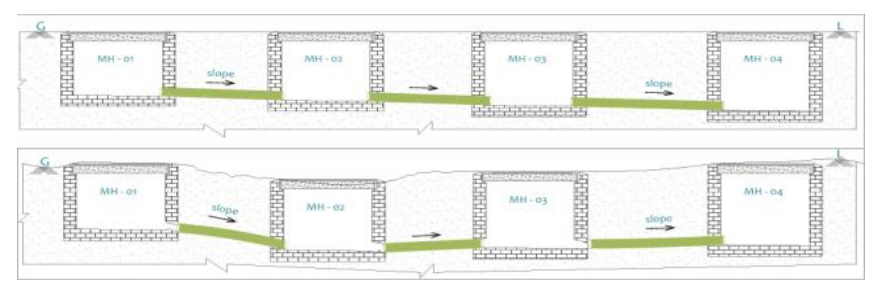

$\underline{\text { Sketch - } 11}$

\section{A.7. Provision of break tanks}

For buildings up to 30 floors height, it is possible to create different pressure zones using a combination of gravity flow, pressure reducing valves and hydropneumatic pumps to deliver water. Refer drawings $1 / 2 / 3$. But on super sky scrapers it is essential to provide for space to provide for break tanks at every 25 floors ( say). At these floors a service plenum will be required to route the water supply pipe work. These break tanks will allow for a more efficient design of the pumping systems and will be more energy efficient.

\section{Drg no.1 (Attached as Colour and Black \& White) \\ Drg no.2 (Attached as Colour and Black \& White) Drg no.3 (Attached as Colour and Black \& White)}

\section{A.8. Terrace Design for efficient discharge of rain} water

Rain water with a horizontal outlet ( surface drain ) is many times more efficient than a side outlet. Consequently if this aspect is taken care of during the structural design incorporating peripheral drains and optimally designed outlets the number of rain water pipes can be drastically reduced. There are proprietary drain outlets available as shown in the pics -3 and 4.

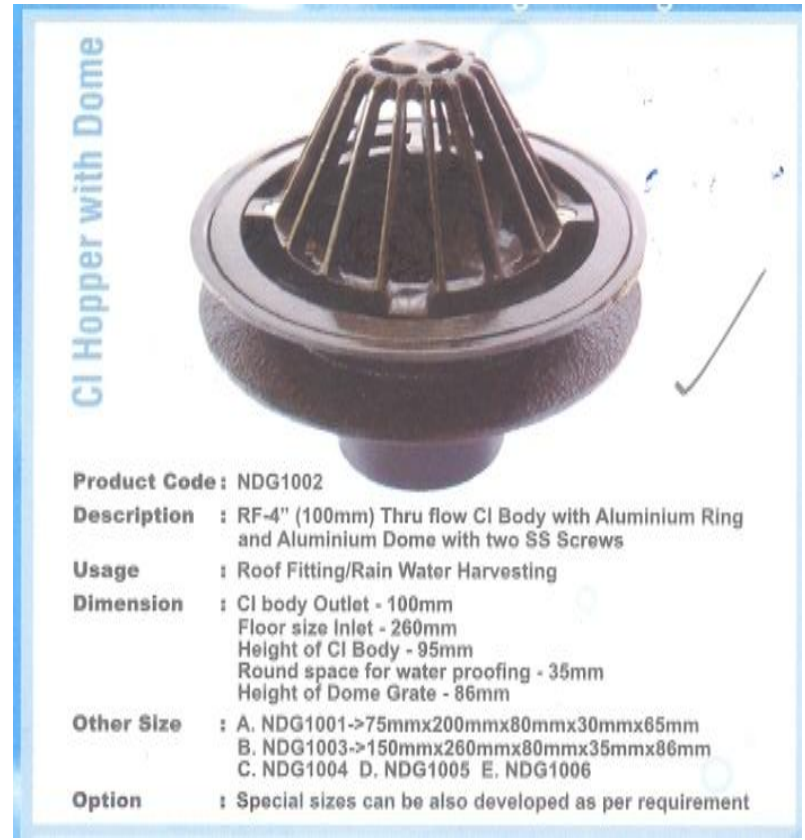

Pic-3

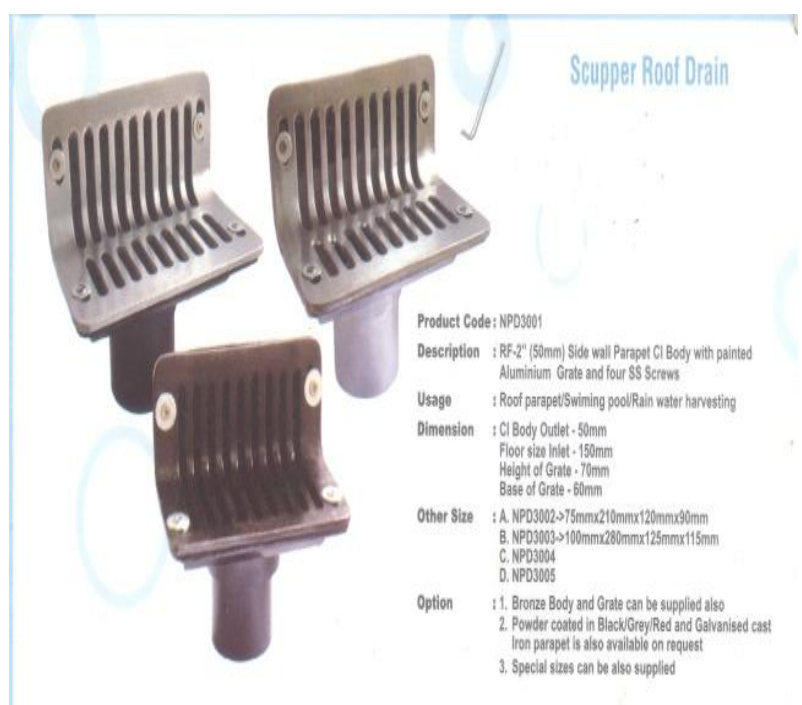

Pic-4

\section{A.9. Heights of Floors}

This is especially relevant in basements and other areas where services especially plumbing, airconditioning, exhaust systems, electrical systems etc have to be installed within the false ceiling plenum. We opine that here also, plumbing, especially drainage systems need to be given precedence. This is primarily because drainage is invariably governed by laws of gravity and have to be laid at a slope.

The foregoing details the possible points of conflict between plumbing installations and structure and the way forward for their effective and efficient resolution. However, to provide a complete picture of the requirement. 
A.10. Drainage and Venting.

Strict principles have been laid out to design sizes of drains and vents. Uniform Illustrated Plumbing Code -2014 . The designs are based on probability of use and the type of use. As per this Code there are three types of uses.

- Private (Eg. Baths in Residences, Baths attached to Hotel Rooms)

Public (Eg. Toilets attached to Restaurants)

- Assembly ( Eg. Toilets attached to Arrival Lounges of Airports, Toilets attached to Conference Halls)

\section{Part - B Evolution of the Modern Plumbing Engineer}

These days it is not enough for a Plumbing professional to be proficient only in hydraulics. The influx of modern products increased awareness on hygiene, greater aspiration for higher aesthetics and a host of other factors have increased he demands on the Plumbing Engineer.

He has to incorporate the sensibilities and needs of :

\section{B.1 Architect / Interior Designers}

- PLUMBING FIXTURES TO BE COORDINATED WITH TILE PATTERNS

- $\quad$ SOLUTIONS FOR A BATH WITHOUT DIPS

- POSITIONING / SIZE OF DOORS \& VENTILATORS

- $\quad$ AESTHETIC INSTALLATIONS

- POSITIONING OF SENSOR APPLIANCES

- $\quad$ ERGONOMICS

B.2 Structural Engineer

- DEPTH OF SUNKEN FLOOR

- $\quad$ SIZE AND POSITIONING OF BEAMS

- EXPANSION JOINTS

- CONSTRUCTION OF WATER TANKS

- ROOF / TERRACE SLOPES FOR RAIN WATER DOWNTAKES.

- KNOWLEDGE OF PRESTRESSED

- CONCRETE ELEMENTS

B.3 Soil Mechanics Engineer

KNOWLEDGE OF SOIL
POROSITY TO DETERMINE
TYPE OF SEEPAGE PIT /
TRENCHES
RAINWATER HARVESTING
KNOWLEDGE OF SOIL
CHARACTERISTICSTO
DETERMINE
TYPE OF MANHOLES /
INSPECTION CHAMBERS

B.4 Hydrologist

- KNOWLEDGE OF LEVEL OF UG WATER TABLE

- AQUIFIERS

- SOURCE OF GOOD WATER

\section{- $\quad$ POSSIBILITY OF SALINE INGRESS}

B.5 Physically Challenged

- PRODUCTS LIKE:

- HEIGHT ADJUSTABLE SANITARY APPLIANCES

- SOLUTIONS FOR BARRIER FREE TOILET SPACE

- SPACE FOR MANOEUVARABILITY OF WHEEL CHAIR

- $\quad$ SLIP-PROOF FLOORING MATERIALS

- TOUCH FREE APPLIANCES

\section{B.6 Environmental Engineer} WATER CONSERVATION RE-USE OF WATER RAINWATER HARVESTING
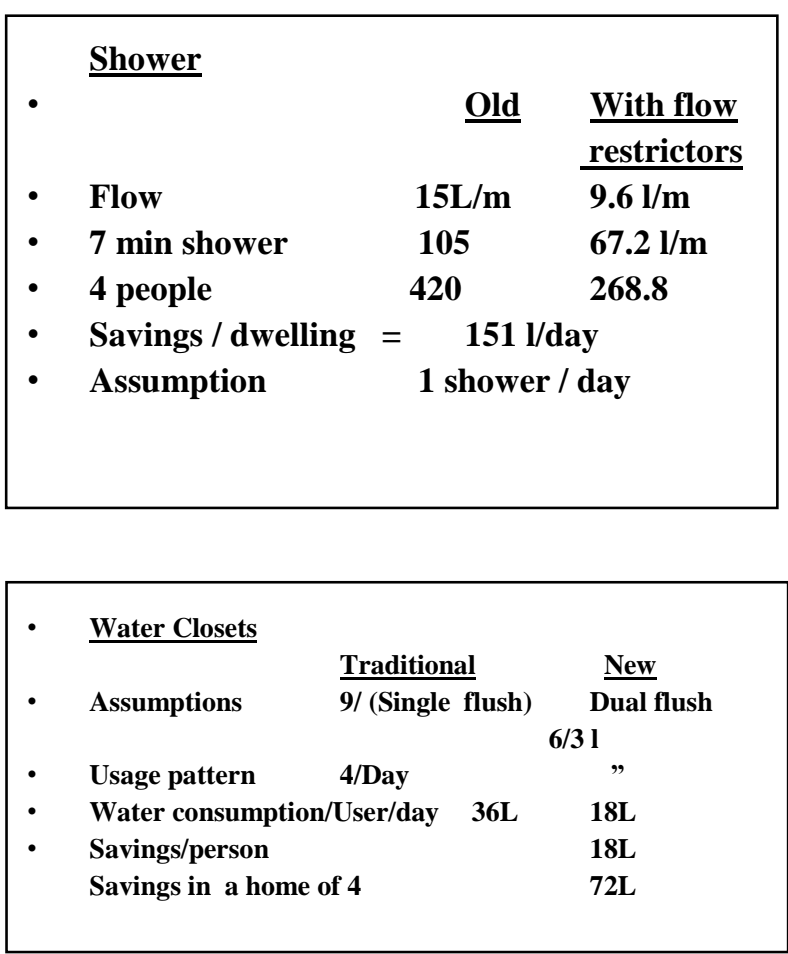

B.7 Acoustic Engineer

$\begin{array}{lll}\text { - } & \text { SOUND PROOF PIPING } \\ \text { - } & \text { SOUNDPROOFING } & \\ & \text { LINED CLAMPS } & \\ \text { - } & \text { INSULATION MATERIAL FOR } \\ & \text { PIPES } & \\ \text { - } & \text { SOFT CLOSE SEAT COVERS } & \\ \text { - } & \text { SOFT FILL MECHANISM FOR } \\ \text { - } & \text { CISTERNS } & \\ \text { - } & \text { SOUND INSULATED DUCTS } & \\ & \text { SOUND INSULATION } & \text { FOR } \\ & \text { WATER CLOSETS } & \end{array}$

B.8 Electrical/Electronics/Instrumentation Engineer $-\quad$ VFD
SYSTEMS
HYDROPNEUMATIC 


\section{- $\quad$ SOLENOID VALVES \\ - AUTOMATIC LEVEL \\ CONTROLLERS \\ - DIGITAL WATER VOLUME MEASUREMENT \\ - $\quad$ SENSOR APPLIANCES}

\section{B.9 Meteorologist}

- RAINFALL CHARACTERISTICS

- TO DESIGN RAIN WATER DRAINAGE

- TO DETERMINE TIME WINDOW WHEN EXTERNAL WORKS CAN BE CARRIED OUT

\section{B.10 Health Inspector}

$\begin{array}{lll}\text { - } & \text { UNDERSTAND DANGERS OF } \\ & \text { CROSS CONTAMINATION } \\ \text { - } & \text { BACKFLOW PREVENTERS } \\ \text { - } & \text { NECESSITY FOR AIRGAP IN } \\ & \text { DRAINAGE \& WATER SUPPLY } \\ & \text { CONNECTIONS }\end{array}$

\section{B.11 HVAC Engineer}

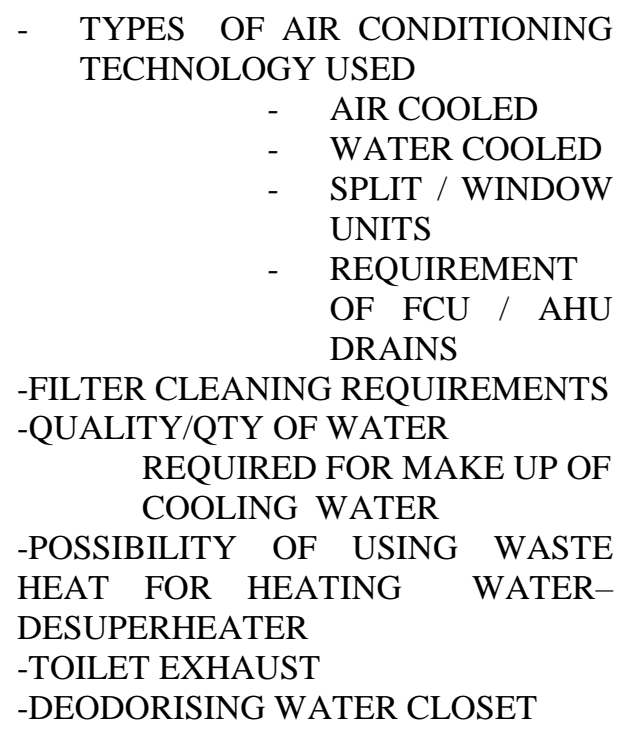

\section{CONCLUSIONS}

In conclusion what to be understood is that plumbing is a branch of engineering caught in a twilight zone between civil and mechanical predominantly. Every aspect of the installation has to be designed and enough codes and installation manuals exist to handle this professionally. The plumbing professional has a greater responsibility to the public as it is the only building service which ( As per WHO guidelines) attach the health of nation.

\section{REFERENCES}

[1]. A Guide to Good Plumbing Practices

[2]Uniform Illustrated Plumbing Code-India-2014

\section{BIOGRAPHY}

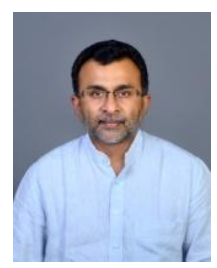

\section{P. Ramachandran}

Managing Director

G R Tech Services Private Limited,

II Floor, Flat No. A 1,

Koparambil Heights,Seaport - Airport Road, Irimpanam P.O.,

Ernakulam, Kerala, PIN Code - 682309.

Tel: +91-0484-2775392/552/9656

Mob: +9193499 16215

EMail : kochi@grtech.co.in

\section{Qualifications :}

Bachelor of Engineering - CIVIL 1983

PSG College of Technology, Coimbatore

\section{Biography/Experience}

P. Ramachandran is a Civil Engineer with 33 years of experience in the field of construction. He began his career with L \& T ECC Construction Group and was with them for 8 years. Since 1991, he has been in the field of plumbing. After a 12 year stint with M/s. ESSENCO, he started his own company called G R Tech Services Pvt. Ltd. in 2003 . Operating out of its headquarters in Cochin, Kerala, G R Tech has executed Plumbing and Fire fighting installations for Hotels, Hospitals, Software Tech Parks, Mass housing, Malls, Resorts etc. in South India.

$\mathrm{He}$ is a life member of Indian Plumbing Association and a constituent of IPA's National Executive Committee. A member of IPA's Technical Committee since its inception, he has been actively involved in the creation of :

- Uniform Illustrated Plumbing Code - India ( UIPC - I)

- Green Plumbing Supplement - India

- Uniform Swimming Pool Code - India

- Uniform Solar Energy Code- India

- Water Efficient Products - India

- A Guide to Good Plumbing Practices

He was also a member of the Editorial Board of Indian Plumbing Today the technical magazine of IPA. He represented IPA as its alternate member on the panel for the Section on Plumbing Services in the National Building Code (India) 2005. P. Ramachandran is also an affiliate member of the World Plumbing Council.

Mr. P. Ramachandran is also:

( A member of the Governing Council of College of Architecture - Trivandrum

(4) A training faculty with Credai.

(4) Chairman of the Advisory Board of the Additional Skill Acquisition Programme of the Kerala Government. 